\title{
A HUNDRED AND TEN YEARS OF THE CONSTITUTION.-PART $\mathrm{X}$.
}

It can hardly be necessary to remind the reader that we are indebted to Mr. Madison for almost all we know of the proceedings of the Convention. Yates, it is true, took short minutes, during the time he attended. But it is to Mr. Madison that we must look for extended information. Writing many years later, he tells us that he had determined to preserve as well as he could an exact account of what passed in the Convention "whilst executing its trust; with the magnitude of which I was duly" impressed, as I was by the gratification promised to future curiosity by an authentic exhibition of the objects, the opinions, and the reasonings, from which the new system of government was to receive its peculiar structure and organization. Nor was I unaware of the value of such a contribution to the fund of materials for the history of a Constitution in which would be staked the happiness of a people great even in its infancy, and possibly the cause of liberty throughout the world." The better to perform his self-imposed task, he chose a seat in "a favorable position for hearing all that passed"- -and carefully noted, in a sort of shorthand, all that was said, writing out his notes daily, or within a day or two, and never being absent from the Convention a single hour of a single day. $\mathrm{He}$ tells us that the radical weakness of the Confederation was "the dependence of Congress on the voluntary and simultaneous compliance with its requisitions by so many independent communities, each consulting more or less its particular interests and convenience and distrusting the compliance of others"-and after reciting some of the consequences of these fundamental defects, he adds that it was to cure these defects that the Convention assembled, and they "ought never to be overlooked in expounding and appreciating the Constitutional Charter, the remedy that was provided." In a letter to Mr. Randolph under date of April 8, I787, in anticipation of the assembling 
of the Convention in the following month, in what I consicler a truly remarkable passage in its clearness, wislom, and foresight. he says "I hold it for a fundamental point that an individual independence of the states is utterly irreconcilable with the idea of an aggregate sovereignty. I think, at the same time, that a consolidation of the states with one simple republic is not less unattainable than it would be inexpedient. Let it be tried, then, whether any middle ground can be taken, which will at once support a due supremacy of the national authority, and leave in force the local authorities so far as they can be subordinately useful." Now, these were Mr. Madison's ideas, before, and long after, the Convention-we have heard him in debate during its sessions-and after noticing a few of his expressions shortly after the adjournment, while its work was being reviewed in Congress and in the various state conventions, let us pass to a consideration of what was done in Congress and in these conventions.

Writing to General Washington on September 30, I787, Mr. Madison says that the answer given to those who contended that Congress could not properly urge the adoption of a Constitution subversive of the very articles to which it owed its existence, was the reason given by Congress for recommending the Convention, viz: that it was the best means of forming a firm National Government (italics in the original) and on October 2oth of the same year he writes Mr. Randolph from New York that the papers in the Northern and Middle States are full of controversial articles, the articles being chiefly leveled against the organization of the government, and the omission of provisions as to juries, etc.-(provisions which would haye been ridiculous in a treaty of alliance). But there is one combatant, it seems, who "strikes at the foundation. He represents the situation of the United States to be such as to render any government improper and impracticable which forms the states into one nation, and is to operate directly on the people." If this is not strong testimony, from friend and foe, as to the contemporary estimation of - what the new government 
really was, it will be hard to find any. Again, writing to the same gentleman in March, 1788 , he says that the owing to certain occurrences "the opposition (to the Constitution) here, which are unquestionably hostile to everything beyond the federal principle, will take new spirits." (Italics in the original.)

The Convention transmitted the results of its labors to Congress, accompanied by a letter briefly stating the general reasons which moved them to recommend the Constitution, saying intcr alia "In all our deliberations on this subject we kept steadily in our view, that which appears to us the greatest interest of every true American, the consolidation of our Union, in which is involved our prosperity, felicity, safety, perhaps our national existence."

Congress at once resolved unanimously to trainsmit the Constitution to the legislatures of the several states in order that they might be submitted to a specially chosen Convention in each state for ratification. We must consider the debates in the various state conventions with some care. If the general Convention framed the Constitution, these conventions ratified it, and their conception of its meaning is therefore most important. Let us begin with the debates in the then leading Commonwealth-Virginia.

Virginia did not hold her Convention for the consideration of the Constitution until June, I788; in the meantime eight states had ratified it, a point upon which much stress was laid in the debates. The Convention was a large body, consisting of about one hundred and seventy members. Several of the delegates to the general Convention were also sent to the State Convention, and there were also present a number of well known and distinguished men, "with a good many more of a lesser degree." As is usual in such cases, comparatively few took the floor at all, and still fewer took a really active part in the deliberations, and, also as usual, several gentlemen were constantly on their feet, notably Patrick Henry, who had refused to serve as a delegate to the general Convention. The Constitution does not seem to 
have been considered with very great particularity. Many of its provisions, incleed, were not discussed at all. But the gencral nature of the instrument was discussed almost ad nauseam. Much real ability was displayed, and on the other hand, much wild, absurd talk was inclulged in, that must have sorely tried the patience of the saner minds in the Convention. There was also, of course, some more or less adroit mancuvring; and no doubt a great deal that was said was dictated by motives of self-interest, direct or indirect. By most of the opponents of the Constitution, there is shown a distrust of Americans in general, which leads one to wonder that they could look with equanimity upon popular government at all! Mr. Madison, who gave evidence in this Convention as in the general Convention, of extraordinary mental balance, and equally extraordinary tactfulness, after having been wearied with this distrustful attitude of some members for many days, let fall the following words of wisdom, which should be read, learned and inwardly digested by all lovers of good government: "I have observed that gentlemen suppose that the general legislature will do everything mischievous they possibly can, and that they will omit to do everything good which they are authorized to do. If this were a reasonable supposition, their objections would be good. I consider it reasonable to conclude that they will as readily do their duty as deviate from it; nor do I go on the grounds mentioned by gentlemen on the other side-that we are to place unlimited confidence in them, and expect nothing but the most exalted integrity and sublime virtue. But I go on this great republican principle, that the people will have virtue and intelligence to select men of virtue and wisdom. Is there no virtue among us? If there is not, we are in a wretched situation. No theoretical checks, no form of government, can render us secure. To suppose that any form of government will secure liberty or happiness without any virtue in the people, is a chimerical idea. If there be sufficient virtue and intelligence in the community, it will be exercised in the selection of these men; so that we do not depend on their virtue, or put con- 
fidence in our rulers, but in the people who are to choose them."

In general, the argument against the Constitution may be said to have been: that it formed a consolidated government to the practical annihilation of the state governments, and by so doing endangered the liberties of the people and paved the way for the establishment of a despotism: that the power of direct taxation would produce a conflict of authority between the national and state tax-gatherers, and as the National Constitution was to be the supreme law of the land, the state authorities must go to the wall: that it therefore placed Virginians at the mercy of a majority from other states, who might impose taxes on Virginian and Southern products, etc., and that it contained no bill of rights to protect the people against deprivation of the right of trial by jury, freedom of the press, etc., and that Virginia should not assent to it without previous amendments explicitly securing these and kindred rights, and in express terms reserving to the states all powers not delegated to the general government. The most bitter and violent opponent of the Constitution was Patrick Henry, whose fertile brain and lively imagination conjured up all sorts of horrors as certain consequences of its adoption. The opposition were never tired of pronouncing the Constitution a scheme for a great consolidated (i. e. centralized) government sometimes asserting that it was "admittedly" so, expecting, we must suppose, to play upon the alarms of the people, always tenacious of local self-government and of their liberties, and to embarrass the supporters of the Constitution, who could not deny that it meant a certain degree of consolidation, and were put to great pains to show that great care had been taken to prevent undue centralization, and to preserve as far as compatible with a firm National Union, not only the local authority of the states, but their existence as distinct political entities.

The Convention plunged at once in medias res. It was hardly fairly organized before $\mathrm{Mr}$. Henry started the ball rolling, by asking by what authority the general Convention had used the words "we the people" instead of "we 
the states" in the preamble?

(A point which oddly enough had caused little or no discussion in the General Convention.) He said that it was "demonstrably clear that a great consolidated government was to be formed instead of a Confecleration." As to the expression "we the people" he was replied to by Mr. Randolph, Mr. Pendleton, Mr. Lee, and Mr. Corbin-by Mr. Randolph by the counter question "Why not?"-since the government was for the people, and that it was a misfortune that the people had no agency in the government before. By Mr. Pendleton by the question "Who but the people have the right to form governments," or delegate powers? and he intimated that the state government had nothing to do with it. By Mr. Lee, that it was a proper expression because the government was to operate on the people, if adopted. By Mr. Corbin, to substantially the same effect.

Mr. Henry adhered stubbornly throughout the entire sessions to his assertion that the government would be consolidated and utterly unfederal, although to use his own words, it had been alleged "to be national and federal as it suited the arguments of gentlemen," and toward the close of the session, Mr. Dawson said that its friends had "admitted that it possesses few federal features, and will ultimately end in a consolidated government, a truth which in my opinion they would have denied in vain; for every article, every section, every clause, almost every line, proves that it will have this tendency." Mr. Mason, a former member of the general Convention, was equally positive. Mr. Grayson did not feel obliged to accept something ' juite different from the Confederation.

The defenders of the Constitution nowhere denied that it was radically different from the Confederation articles. Mr. Lee denied that it was conceded to be a "National" (centralized) government, and once more we have $\mathrm{Mr}$. Madison as the clearest exponent of the true intent of the Constitution as framed. He says it differs radically from the confederation in that it forms a government partly consolidated, partly federal. "It is in a manner unprecedented; we cannot find one express example in the experience of the world. It stands by itself. * * I can say 
notwithstanding what the honorable gentleman has said that this government is not completely consolidated, nor is it entirely federal. Who are parties to it? The people,- - but not the people as composing one great body; but the people as composing thirteen sovereignties. * * Should all the states adopt it, it will be then a government established by the thirteen States of America, not through the intervention of the legislatures, but by the people at large. In this particular respect the distinction between the existing and proposed government is very material. The existing system has been derived from the dependent derivative authority of the legislatures of the states; whereas this is derived from the superior power of the people. If we look at the manner in which alterations are to be made in it, the same idea is, in some degree, attended to. By the new system, a majority of the states cannot introduce amendments; nor are all the states required for that purpose. * * In this there is a departure from the federal idea. The members of the $\mathrm{Na}$ tional House of Representatives are to be chosen by the people at large in proportion to the numbers in the respective districts. When we come to the Senate its members are elected by the states in their equal and political capacity. But had the government been completely consolidated, the Senate would have been chosen by the people in their individual capacity, in the same manner as members of the other house. Thus it is of a complicated nature." In spite of this, the assertion was again and again made afterwards by the enemies of the Constitution that it meant a consolidated government pure and simple, to all practical intents and purposes. In defending the Constitution, it was not difficult to show how unfounded were the fears and gloomy prognostications as to loss of liberty, despotism, etc., to the more logical minds. The forced and strained construction put upon the words of the Constitution by its opponents was so grotesque at times as to excite disgust. But what could not be denied was, that the new government would be essentially different from the old, that it would act directly upon the people in many instances. And the main 
struggle was really as to whether a bill of rights and cognate amendments should be required as a condition precedent to Virginia's assent.

The absolute necessity of Union was insisted upon over and over again, and in the strongest terms, by the advocates of the Constitution, and the establishment and perpetuation of that Union was declared to be the main object in forming the Constitution. Mr. Randolph calls the Union "the anchor of our political salvation," and equally strong expressions are quite frequent. And now let us examine the proceedings of the Convention a little more in detail. It was determined at the outset to consider and clebate the Constitution "clause by clause," and yet in practice the rule was at once departed from, owing to $\mathrm{Mr}$. Henry's vehement and passionate condemnation of the Constitution as a whole, which brought forth replies and counter replies, so that more than one-half in volume, and about one-half in time, of the debates in the entire session was devoted to a general discussion, quite desultory in character. with the first and second sections of Article I nominally under consideration; the third section was not read until June $I_{4}$ th; the Convention assembled on June $2 d$ and concluded its debates on June 25 th, adjourning two clays later. So far as we are at present concerned the first "particular" discussion of any importance arose as to the clause of Article I, Section 8, which gives Congress power to call forth the militia to execute the laws of the Union, etc., to which it was objected that by this too much power was taken from the states and given to the general government, and that it would lead to the establishment of a standing army; and further that Congress might drag the militia to immense distances. To this Mr. Madison replied that the existence and control of the militia was the best guarantee that a standing army would not be necessary, and that the abuse of power in dragging the militia to immense distances was not likely to occur where there was a "government of a federal nature, consisting of many co-equal sovereignties, and particularly having one branch chosen by the people." As to taking the militia away from the 
state governments, he stated that the Congressional power over it was concurrent, not exclusive. And when a little later it was contended by the alarmists that under the Constitution, if the state governments had any control over the militia it was by implication, Mr. John Marshall replied that the state governments did not derive their power from the general government; but each government derived its powers from the people, and each was to act according to the powers given it. There was also quite a discussion as to the clause giving Congress the power of exclusive legislation over a district ten miles square. It was fraught with terrible dangers to the liberties of the people inhabiting the vast area outside of it, thought Mr. Mason; the district would become a sort of sanctuary for the blackest criminals, and for fugitive slaves, etc., etc. Even at this late date, it is difficult to keep one's temper in reading such balderdash!

When the ninth section was read, Mr. Henry rose and declared that this section was really a bill of rights, that it prescribed the limits beyond which Congress could not go. He argued that outside of these prohibitions, they could do what they pleased, and as in his judgment this "bill of rights" was totally inadequate for the protection of the liberties of the people, a more substantial provision in the shape of a real bill of rights should go in. The argument was plausible, certainly, and there could be but one answer to it, namely, that the restrictions were exceptions to particular powers, express or implied, and not to a general power. This was the answer made by $\mathrm{Mr}$. Randolph, and elaborated by him. In some instances, his ingenuity was taxed a good deal to find the particular power abridged, but as a matter of fact, wherever the power is hard to find, the restriction is unnecessary. For even had the Constitution been silent on the subject, it is hard to find where Congress had been expressly or impliedly authorized to grant titles of nobility, for example. As to the tenth section (containing restrictions upon the powers of the states) there was comparatively little discussion, and most of the objections were of a temporary character. Now, it is noteworthy 
that many highly important and highly sovereign powers conferred upon Congress and taken from the states were not discussed at all, but passed, as it were, sub silentio. For example: (I) The power to lay duties on imports. (2) To regulate commerce. (3) To establish uniform naturalization laws. (4) To coin money, etc. (5) To declare war, etc. In a discussion at a later stage (Art. II, Sec. 2), which we need not now follow in detail, some significant remarks were made of a general nature. Mr. Grayson said the Constitution would be the "Great Charter" of America. "After having once consented to it, we cannot recede from it." And Mr. Randolpli said that it followed from the nature of civil association that no particular part shall sacrifice the whole. And Mr. Corbin contended that the "empire" could not be dismembered without the consent of the part dismembered. When the question of the propriety of the establishment of inferior federal courts was under discussion, and it was warmly debated, Mr. Mason said that he believed that the Constitution was intended to destroy the state governments, and gradually bring about one great, national consolidated government, which many gentlemen in the United States thought advisable. Mr. Madison interrupted to ask to whom he referred, as without explanation his hearers might think he referred to all the members of the late Convention, to which Mr. Mason replied that he had not referred to any one from Virginia, but it was notorious that it was "a prevailing opinion," with which explanation Mr. Madison declared himself satisfied. Whether this statement was a shrewd move on the part of Mr. Mason to prejudice the minds of the members, or whether he really believed what he said, it is impossible to say. Mr. Madison very naturally declined to be placed in a false position. For there can be no question that any truly consolidated, centralized government, annihilating the state governments, would never have been set up by the American people at that time, or since, for that matter. And we have seen in an examination of the debates of the general Convention that no such a view as that stated ly Mr. Mason was held except possibly by the very few extremists, if 
indeed by anyone. It is the old difference between a $\mathrm{Na}$ tional and a Centralised government, by no means synonymous terms. In the words of Mr. Pendleton, "I should understand a consolidated government to be that which should have the sole and exclusive power, legislative, executive and judicial, without any limitation." And such a government it is ridiculous to say that the Constitution was intended to establish either all at once or gradually by its general tendency. As before suggested, the absence of a bill of rights and of a specific declaration that all powers not granted were reserved, inclined some members to insist upon their insertion as a condition precedent to ratification; while others felt that while not expressed, a bill of rights was clearly understood, and that by the very nature of the instrument the government organized under it could only have the powers conferred by it, and moreover, that an incomplete bill of rights was worse than none; and that it would be far worse to imperil the Union by insisting on amendments to the Constitution previous to its adoption, than to trust to proper amendments being made afterwards. It had been suggested that in ratifying the Constitution, the Convention should insert a declaration to the effect that all the powers in the Constitution were derived from the people and might be rescinded by them whensoever they should be perverted to their injury or oppression, a self-evident truth, it would seem; and Mr. Nicholas, a friend to the Constitution, argued that there could be no danger in adopting it in this way, "for these expressions will become a part of the contract. The Constitution cannot be binding on Virginia but with these conditions. If thirteen individuals are about to make a contract, and one agrees to it, but at the same time declares that he understands its meaning, significance, and intent to be (what the words of the contract plainly and obviously denote) that it is not to be construed so as to impose any supplementary conditions upon him, and that he is to be exonerated from it whensoever any such imposition shall be attempted. I ask whether, in this case, these conditions, on which he assented to it, would not be binding on the other twelve. 
In like manner these conditions will be binding on Congress. They can exercise no power that is not expressly granted to them." With the soundness of this view we need not now concern ourselves; and whether they really expressed Mr. Nicholas belief is not certain; he was arguing in favor of the adoption of the Constitution and encleavoring to quiet the fears of the more sensitive as to undue centralization as a result of adoption without previous amendments. No comment was made upon $\mathrm{Mr}$. Nicholas' remarks, and no one else made the same argument. On the contrary, the argument of the opponents of the Constitution was that after ratification it would be too late to securc amendments, possibly they might be made, and possibly not. Mr. Innes said that in his opinion all the Convention could do was to accept or reject the Constitution, not to accept conditionally. The final result of the deliberations was, that by a vote of eighty-nine to seventy nine, the Constitution was ratified in the following form: "VIRGINIA, to wit: We, the delegates of the people of Virginia, duly elected in pursuance of a recommenclation from the General Assembly, and now met in Convention, having fully and freely investigated and discussed the proceedings of the Federal Convention, and being prepared, as well as the most mature deliberation hath enabled us, to decide thereon, Do in the name and in behalf of the people of Virginia, declare and make known, that the powers granted under the Constitution, being derived from the people of the United States, be rescinded by them whensoever the same shall be perverted to their injury or oppression, and that every power, not granted thereby remains with them and at their zoill (italics in the original); that, therefore, no right, of any denomination, can be cancelled, abridged, restrained, or modified, by the Congress, by the Senate or House of Representatives, acting in any capacity, by the President, or any department or officer of the United States, except in those instances in which power is given by the Constitution for those purposes; and that, among other essential rights, the liberty of conscience and of the press cannot be cancelled, abridged, restrained, or 
modified by any authority of the United States. With these impressions, with a solemn appeal to the Searcher of hearts for the purity of our intentions, and under the conviction that whatsoever imperfections may exist in the Constitution ought rather to be examined in the mode prescribed therein, than to bring the Union into danger by delay, with a hope of obtaining amendments previous to the ratification, $W e$, the said delegates, in the name and behalf of the people of Virginia, do, by these presents, assent to and ratify the Constitution, recommended on the seventeenth day of September, one thousand seven hundred and eighty-seven, by the Federal Government for the United States; hereby announcing to all whom it may concern that the said Constitution is binding upon the said people, according to an authentic copy hereto annexed," etc. They then proceeded to draw up certain amendments to the Constitution, to be submitted to the first Congress assembled under it. The first of these was, that there should be a bill of rights attached to the Constitution "in some such manner" as the following, which is too long to transcribe. It consisted of twenty paragraphs, the first seven setting out somewhat in detail the principles of popular self-government, the balance setting out fully and explicitly the great personal rights for which our forefathers contended in and before the Revolution. In addition to the bill of rights, they recommended twenty other amendments, only a few of which we need notice just now: (I) "That each state in the Union shall respectively retain every power, jurisdiction, and right, which is not by this Constitution delegated to the Congress of the United States, or to the departments of the Federal Government." (3) "When Congress shall lay taxes or excises, they shall immediately inform the executive power of each state of the quota of such state, according to the census herein directed, which is proposed to be thereby raised; and if the legislature of any state shall pass a law which shall be effectual for raising such quota at the time required by Congress, the taxes and excises laid by Congress shall not be collected in such state." A motion to strike this amendment from the 
list of those recommended failed by a vote of eighty-five to sixty-five. (II) The eleventh suggested amendment gave the states the control of the militia except when in the actual service of the United States. (I2) The twelfth suggested amendment limits the power of Congress over the "ten miles square" district to such regulations as respect "the police and good government thereof." (I4) The fourteenth suggested amendment limits the jurisdiction of the United States Courts, calls the inferior courts "Courts of Admiralty," and entirely abolishes federal jurisdiction between citizens of different states. (I6) The sixteenth suggested amendment limits the power of Congress to regulate elections to cases in which the legislature has been unable, or has neglected, to do so. (I7) The seventeenth suggested amendment provides that clauses declaring that Congress shall not exercise certain powers are not to be interpreted so as to extend the power of Congress, but taken as exceptions to specified powers, or "as inserted merely for greater caution."

Lucius S. Landreth. 